\title{
Support for Organic Beekeeping in Romania: A View for the Next Rural Development Programming Period
}

\author{
Sorin L. ŞTEFĂNESCU*1), Liviu Al. MĂRGHITAȘ²), Monica DUMITRAŞCU ${ }^{1)}$, Roxana VIDICAN²), \\ Karl M. ORTNER ${ }^{3)}$ \\ ${ }^{1)}$ National Research and Development Institute for Soil Science, Agro-Chemistry and Environment-ICP, \\ 6 Mărăşti Blv., 011464 Bucharest, Romania \\ 2)University of Agricultural Sciences and Veterinary Medicine, 3-5 Mănăştur Street, 400372 Cluj- \\ Napoca, Romania \\ ${ }^{3)}$ GBI Consulting, Schwarzenbergplatz 6, A-1030, Vienna, Austria \\ *Corresponding author, email: sic.stefanescu@gmail.com
}

Bulletin UASVM Animal Science and Biotechnologies 71(2) / 2014,

Print ISSN 1843-5262; Electronic ISSN 1843-536X

DOI:10.15835/buasvmcn-asb:10298

\begin{abstract}
Organic farming is a continuously growing sector in EU. Recognizing its important contribution to various rural development objectives and priorities, the new Regulation on support for rural development by the European Agricultural Fund for Rural Development has established a distinct and specific voluntary "Organic Farming" measure for the period 2014-2020. Since 2006, the organic land area in Romania has increased constantly. Thus, the operational objective of the organic farming measure for the next rural development period would be the doubling of the existing organic certified land to over $4 \%$ of the total Utilized Agricultural Area by 2020 . Based on the expectations that the new organic farming measure, currently under the design process in Romania, will continue improving the previous approach of the existing national Rural Development Program, the present paper aims to provide a view on including beekeeping under the eligible types of support and to assess the related applicable amounts and support rates for the "Organic Farming" measure. The calculated rate for support results from the additional costs incurred by undertaking organic beekeeping. As regard to income foregone, the differences overall between organic and conventional practices are almost insignificant. The minimum proposed rate applies to both conversion to and maintenance of organic practices.
\end{abstract}

Keywords: apiculture, income foregone, organic farming, public goods, rural development

\section{INTRODUCTION}

In response to the increasing concern for the environmental issues, particularly with regard to biodiversity loss, climate change, soil, water and air pollution and depletion of natural resources, organic farming has become an important aspect of the European agri-environmental policy. The positive effects of organic farming practices to the environment have been systematically studied during the last decades. In that sense, the most comprehensive environmental indicator assessment revealed clear results (Stolze et al., 2000). Since late 90's, Romania has also joined the European research area concerning the environmental benefits of organic farming (Dumitru et al., 2000).

Over the last years, Romania has seen a steady and rapid rise in the amount of land and number of holdings adhering to organic standards. The relative low level of pollution in Romanian's agriculture continues to provide good opportunities for conversion to organic practices and the organic yields may reach a satisfactory level under a proper management (Stefănescu et al., 2010). In 2012, organic land accounted for $2.1 \%$ of the total Utilized Agricultural Area (UAA) (Fig. 1). 
Since 2006, the organic land area increased from 107,582 ha to 288,261 ha in $2012(+268 \%)$ and the number of organic certified operators increased 4.6 times from 3,409 to 15,554 (Eurostat, 2012). Between 2006 and 2012, the most spectacular increase has been recorded on the "organic in conversion" land (+436\%), mainly in the last two years (as Romania has implemented the organic farming scheme since 2010), emphasizing that area support payments consistently stimulate at initial stages the development of organic production. In 2012, the potential for growth (meaning area under conversion as a percentage of the total organic area giving an indication of the potential growth in the organic sector in the years to come), was considerable: $64.2 \%$.

In Romania, the domestic organic market is just developing and there is a lack of viable data on its size. Consumption of organic products although growing slowly, is still a small fraction of total food purchases. The sales of organic products in Romania in 2011 reached roughly 1\% of the entire Romanian food retail market. The exports reached 200 mil. $€$ (twice higher than in 2010), whilst domestic market reached 80 mil. $€$ with a steady annual growth of $20 \%$ (Burcă-Voicu, 2012). However, most of the local consumption is covered from imports. Romania is still a net exporter of organic raw materials. As the processing sector is insufficiently developed (in fact, the entire organic supply-chain is still under development), many organic products are sold as conventional products. However, the availability of organic food has improved significantly in the last two years, mainly due to the interest of retail chains. Currently almost all super - and hypermarkets retail organic food and play as the most important market channels for organic food in Romania. The positive trend of organic production and market was acknowledged in Biofach Nuremberg 2013: Romania was nominated as Country of the Year.

Under the still running Rural Development Program 2007-2012, Romania has implemented a specific organic farming scheme as a sub-activity of Axis 2, Measure 214, to cover the additional costs or income forgone of undertaking organic farming. Since 2010, the Measure 214 was only used for maintenance payments (euro per ha), for arable land (including forage crops), annual vegetables (including mushrooms and potatoes), herbs and perennials (orchards and vineyards). The level of compensation for additional costs resulting from organic farming management was $100 \%$ (as most of the other EU counties).

In recognition for the importance of organic farming in contributing to various rural development objectives and priorities, for the programming period 2014-2020, the Commission established a specific voluntary Organic farming measure in Article 29 of the Regulation (EU) No

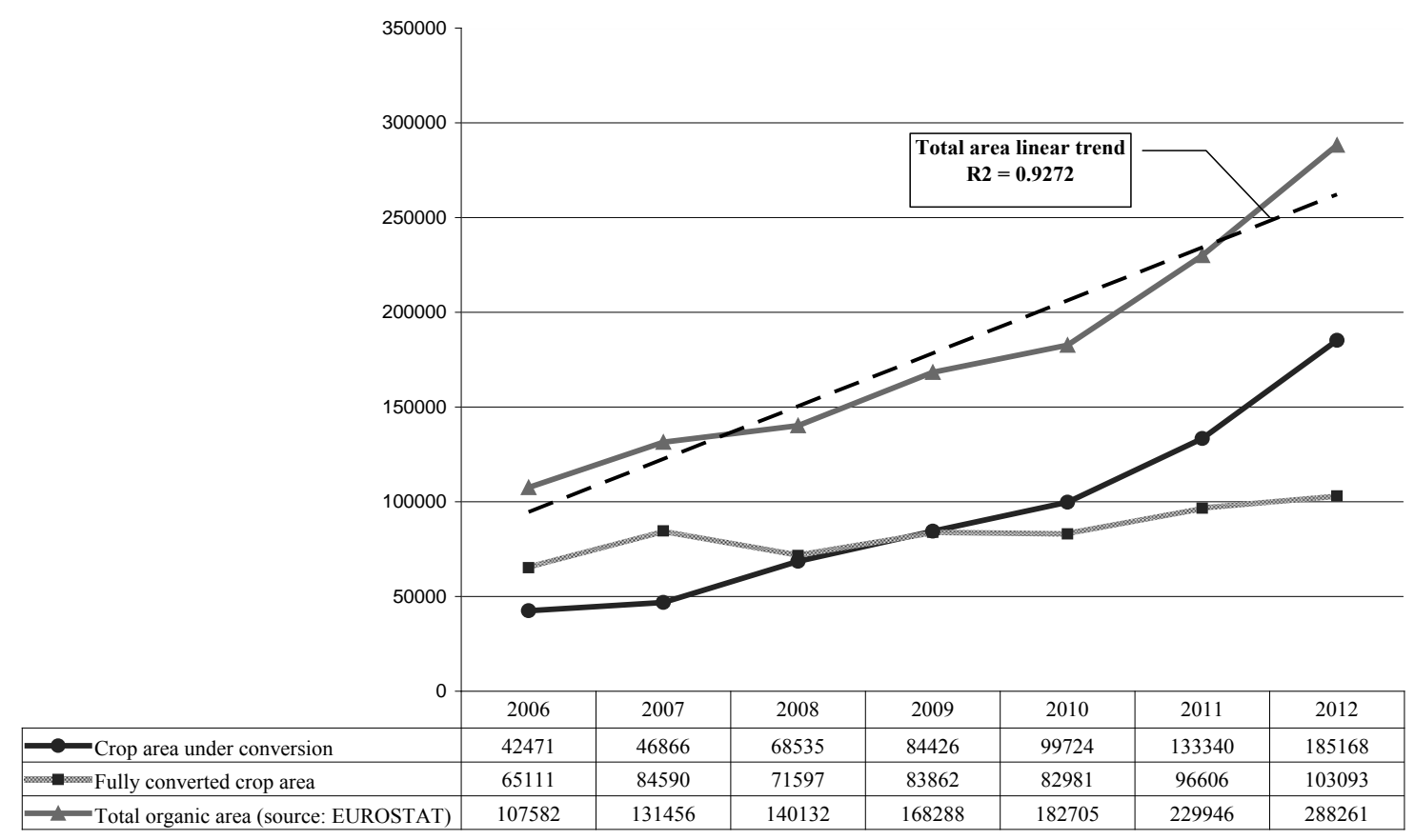

Fig. 1. Dynamic of the organic certified land in Romania (ha) 
$1305 / 2013$ of the European Parliament and of the Council of 17 December 2013 on support for rural development by the European Agricultural Fund for Rural Development (EU a, 2013).

The Commission view is that payments to farmers for the converting to, or maintaining, organic farming should encourage them to participate in such schemes thereby responding to the increasing demand of society for the use of environmentally friendly farm practices and for high standards of animal welfare. Moreover, the support for converting to organic and for maintaining organic management practices is also considered as contributing to the provision of the broad range of public goods (Cooper et al., 2009).

During the programming period 2007-2013, the European Commission (DG AGRI) financed an external study to investigate support to organic production (Sanders et al., 2011). In "Annex 1: National Inventories", the study provides a list of the levels of payments to organic bee producers, which are applied by different Member States. The payment rates for conversion range from $7 €$ per beehive in Spain-Asturias to $33 €$ in Spain-Galicia (there for only 1 hive per ha). For maintenance the range starts at $6 €$ per beehive in Spain-Asturias (for at least 20 beehives) and ends at $28.5 €$ per beehive (for only 1 hive per ha) in Spain-Galicia. Bulgaria paid $12 €$, Austria $25 €$ and Spain-La Rioja $28 €$ per beehive for both conversion and maintenance.

In Romania, the support for beekeeping was provided for farms under conversion only, in the context of a quality approach, under Article 68 of the Council Regulation 73/2009 (EC, 2009).

\section{MATERIALS AND METHODS}

The organic farming measure aims at encouraging farmers to convert from conventional farming methods and to apply organic farming methods as defined in Council Regulation (EC) No $834 / 2007$ (EC, 2007), as well as to maintain these methods after the initial period of conversion. In both cases, support is paid for carrying out the environmentally favorable production methods, which are intrinsically linked to organic farming. Support shall be granted, per hectare of UAA, to farmers or groups of farmers who undertake, on a voluntary basis to convert to or maintain organic farming practices and methods as defined in Council Regulation (EC) No 834/2007, for commitments going beyond the relevant mandatory standards established pursuant to Chapter I of Title VI (cross-compliance) of the Regulation (EU) No 1306/2013 (EU b, 2013), relevant minimum requirements for fertilizer and plant protection products use as well as other relevant mandatory requirements established by the national legislation. The organic farm must be inspected and certified (as „in conversion to organic" or "organic") to an independent certification body approved by the Romanian Ministry of Agriculture and Development.

For the period 2014-2020, the measure fiche for Article 29 (organic farming) stipulates that: "support for organic farming can only be granted to land defined as agricultural area. This also implies that the support shall be granted per hectare. Payments per livestock units are not to be included. "However, in duly justified cases other units than hectares can be used for the purpose of payments' calculation". It explicitly states that: "support per beehive shall be possible".

According to Chapter 13 (1) of EC Regulation $889 / 2008$ (EC, 2008) "the sitting of the apiaries shall be such that, within a radius of $3 \mathrm{~km}$ from the apiary site, nectar and pollen sources consist essentially of organically produced crops and/or spontaneous vegetation and/or crops treated with low environmental impact..." In Romania, most usually, during the vegetation period the apiaries are transferred from plain to hilly areas to reach different stages of flowering of diverse crops and spontaneous vegetation such as the various mixes of forestry species, hedges and natural pastures on flat land or slopes, with diverse sizes and sometimes discontinuous shapes. For this reason support to beekeeping should be granted per bees' family (beehive) rather than per undefined hectares. The proper size and vegetation quality of the land covered and explored by the bees is subject to inspections, which are carried out by a contracted certification body.

The methodology for the calculation of compensation rates (CRs) is based on the calculation of additional costs and income foregone resulting from the commitments to comply with organic farming practices, by the general formula:

\section{CR per beehive $=$ income foregone + (net) additional costs.}


Since data on yields and producer prices of organic production do not exist in Romania and hardly in other Member States for most of the crops or practices, they have to be estimated on the basis of expert information or assumptions.

To assess the additional costs incurred by organic beekeeping and consequently the minimum level of the payments to support the organic beekeeping, the input prices (organic and conventional) were taken from the best recent offers available, which are displayed by the input provider sites in Romania. The same path was taken (average of the best available prices for organic and conventional honey and wax displayed by honey producers), to assess the income forgone conventional vs. organic. Whereas missing (no sources available) information occurred, the beekeeping research expertise of the University of Agricultural Sciences and Veterinary Medicine in Cluj has provided the necessary input.

Concerning the input for certification costs, the fees for the organic farming are differently structured by the various firms, which provide certification services. There are fees for travel, the size of the operation, the documents, first visit, etc. Easy to understand and to follow up is the structure applied by the company "Austria Bio Garantie" which was used for the calculation of this kind of costs.

\section{RESULTS AND DISCUSSION}

As cross-pollinating vector for flowers, which produce fruit and seeds for growing crops, honeybees are among the most important contributors to the agricultural production in an environmental friendly manner and a sensitive indicator for the crops use of pesticides; thus, it is generally accepted that apiculture is a key incentive for the environment conservation. The support given within Article 29 aims at encouraging beekeepers to apply organic beekeeping methods as defined in Council Regulation (EC) No 834/2007 and to bring even a higher environmental added value to the agricultural/forestry area explored by honeybees.

The support rate depends on the additional costs of organic vs. conventional beekeeping and possibly the income foregone by pursuing organic production methods. In Romania, additional costs are incurred mostly for feeding of bees with sugar (an average of $4 \mathrm{~kg}$ annually per beehive), the rejuvenation of wax within the beehive (an average of $0.5 \mathrm{~kg}$ annually per beehive), and pest control, using Varachet conventional beekeeping and a mix of formic, lactic, acetic and oxalic acid as well as menthol, thymol, eucalyptol or camphor oils in organic beekeeping (6 treatments yearly in each approach, conventional or organic), as provided by the Article 25(6) of the EC Regulation 889/2008 (in cases of infestation with Varroa destructor, Anderson and Trueman 2000). Using the average prices for the inputs organic vs. conventional, the additional costs incurred by organic beekeepers come to a minimum of $11.25 €$ per beehive (Tab. 1).

Other cost items, for example transports costs, are similar for conventional and organic production and therefore neglected in the calculation. In respect of labor costs, the beehive cleaning up involves very small differences: treatments with chlorine salts (conventional) vs. treatments with a mix of acids and oils (organic). Whether both conventional and organic beekeepers use thermal treatment for cleaning, the differences become flat.

As regard to income foregone, the differences overall between organic and conventional prac-

Tab. 1. Additional costs for organic beekeeping in Romania (per beehive)

\begin{tabular}{cccccc}
\hline & & \multicolumn{2}{c}{$\begin{array}{c}\text { Producer prices RON per kg } \\
\text { Item }\end{array}$} & \multicolumn{2}{c}{$\begin{array}{c}\text { Output values RON per } \\
\text { beehive }\end{array}$} \\
\cline { 3 - 6 } & $\mathrm{kg}$ & conventional & organic & conventional & organic \\
\hline Sugar & 4.00 & 3 & 11 & 12.0 & 44.0 \\
Wax & 0.50 & 25 & 35 & 12.5 & 17.5 \\
Medicine & & & 6.0 & 18.0 \\
\hline Total & & 30.5 & 79.5 \\
\hline Additional costs (RON) & & & \\
Additional costs in ( $\left.€^{2}\right)$ & & & \\
${ }^{1}$ Conventional pest control Varachet 1 RON/treatment, 6 treatments/year \\
Organic pest control: Mix of acids and oils, 3 RON/treatment, 6 treatments/year \\
${ }^{2} 1$ EUR = 4.357 RON
\end{tabular}


Tab. 2. Calculation of income foregone by organic production of beehives

\begin{tabular}{cccc}
\hline & Conventional & Organic & Ratio org/conv \\
\hline Honey per beehive, kg/year & 40.00 & 32.00 & $80 \%$ \\
Price of honey, RON/kg & 11.00 & 13.75 & $125 \%$ \\
Value of honey, RON & 440.00 & 440.00 & \\
Wax per beehive, kg/year & 1.10 & 0.88 & $80 \%$ \\
Price of wax, RON/kg & 20.00 & 25.00 & $125 \%$ \\
Value of wax, RON/beehive & 22.00 & 22.00 & \\
\hline Total value of output, RON/beehive & 462.00 & 462.00 & \\
\hline Income foregone, RON/beehive & & 0.00 & \\
Additional costs, RON/beehive & & 49.00 & \\
Compensation rate, RON/beehive & 49.00 & \\
Compensation rate, $€ /$ beehive/year & 11.25 \\
\hline
\end{tabular}

tices are almost insignificant (Tab. 2). Usually the productivity per beehive of honey and wax is similar in conventional and organic production but organic farmers face higher losses of beehives, mostly due to the lower efficiency of the treatments applied. These losses are more or less compensated by higher farm-gate prices of organic honey and wax. Thus the calculated compensation rate for organic beekeeping remains $11.25 €$ per beehive per year. This rate applies to both conversion and maintenance because the period of conversion is 1 year only, as pursuant to Article 38(3) of the EC Regulation 889/2008 (EC, 2008).

Whether certification costs would be included in the payment rate, the support would rise to additional $1.67 €$ per beehive per year, amounting to a minimum overall annual compensation rate of $12.92 €$ /beehive.

\section{CONCLUSION}

Looking to the last years linear trend of organic farming in Romania, the operational objective of the organic farming measure of the National Rural Development Program should be doubling the existing organic certified land to over $4 \%$ of the total UAA by 2020 and to improve significantly the domestic market' absorption of organic products.

An important issue of the new organic farming measure fiche of the next programming period would be such to continue improving the previous approach of the existing National Rural Development Program by including the support for both maintaining and conversion to organic beekeeping.

As less significant differences occurs between conventional and organic beekeeping in terms of income forgone, using the average prices for the inputs organic vs. conventional, the additional costs incurred by organic beekeepers come to a minimum of $12.92 €$ per beehive (including certification costs), concluding the minimum baseline level of the rural development support for apiculture in Romania.

\section{REFERENCES}

1. Austria Bio Garantie GmbH (2014). ABG0260r-Sistem tarifar C-Version 2.0-02.06.2014. Fees for International Inspection and Certification, Available at http://www. abg.at/en/international/fees_int. Accessed in 2014 June 07.

2. Burcă-Voicu M (2012). The Evolution of the Organic Food Market in Romania-Trends, Opportunities and Threats in the Current International Economic Context, Romanian Review of International Studies IV (2): 5-15.

3. Cooper T, Hart K, Baldock D (2009). The Provision of Public Goods Through Agriculture in the European Union, Report Prepared for DG Agriculture and Rural Development, Contract No 30-CE-0233091/00-28, Institute for European Environmental Policy: London, UK, $396 \mathrm{p}$.

4. Dumitru M, Ştefănescu SL, Simion Paranici S, Lungu M (2000). Strategy to Sustainable Agriculture in Romania Danube Basin: An Organic vs. Conventional Agriculture Approach (National Strategy and research findings of the EU Phare Project "Demonstration Centers for Sustainable Agriculture in Danube River Basin and Market Aspects"EU/AR/301/91), Ed. Triade, Cluj.

5. Council Regulation 73 (2009). Regulation establishing common rules for direct support schemes under the common agricultural policy and establishing certain support schemes for farmers and amending Regulations (EC) No 1290/2005, (EC) No 247/2006, (EC) No $378 / 2007$ and repealing Regulation (EC) No 1782/2003. Official Journal of the European Union 52 (L 30): 1-84.

6. Commission Regulation 889 (2008). Regulation laying down detailed rules for the implementation of Council Regulation (EC) No 834/2007 on organic production and labelling of organic products with regard to organic production, labelling and control. Official Journal of the European Union 51 (L 250): 1-84. 
7. Council Regulation 834 (2007). On organic production and labeling of organic products and repealing Regulation (EEC) No 2092/91. Official Journal of the European Union 50 (L 189): 1-23.

8. Regulation 1305 (2013 a). Of the European Parliament and of the Council on support for rural development by the European Agricultural Fund for Rural Development (EAFRD) and repealing Council Regulation (EC) No 1698/2005. Official Journal of the European Union 56 (L 347): 1-487.

9. Regulation 1306 (2013 b). Of the European Parliament and of the Council on the financing, management and monitoring of the common agricultural policy and repealing Council Regulations (EEC) No 352/78, (EC) No 165/94, (EC) No 2799/98, (EC) No 814/2000, (EC) No $1290 / 2005$ and (EC) No 485/2008. Official Journal of the European Union 56 (L 347): 1-549.

10. Eurostat-Data Explorer (2012). Certified organic area by crops products, last update 21-10-2013, [food_in_porg1]. Accessed in 2014 April 21.

11. Sanders J, Stolze M, Padel S (2011). Use and efficiency of public support measures adressing organic farming
Study Report, Braunschweig, Nov 2011, Institute of Farm Economics, Johan Heinrich von Thunen-Institute, Federal Research Institute for Rural Areas, Forestry and Fisheries Germany, Forschungsinstitut für biologischen Landbau (FiBL), Switzerland, Organic Research Centre (ORC), UK, $186 \mathrm{p}$.

12. Stolze M, Piorr A, Haring A, Dabbert St (2000). The Environmental Impacts of Organic Farming in Europe, Organic Farming in Europe: Economics and Policy, vol. 6, University ofHohenheim/Department of Farm Economics, Stuttgart, Germany, ISBN: 3-933403-05-7, 143 p.

13. Ștefănescu SL, Calciu I, Dumitrașcu M, Dumitru E (2010). Effects of the agricultural technologies on soil environment within an organic certified land: recommendation for a reduced tillage, Research Journal of Agricultural Sciences, Agroprint, Timişoara, Vol. 42 (1) 1-688 (2010): 291-298.

14. WWF Romania (2013). Retailer Scorecard 2013, A doua editie a studiului privind performanta de mediu pe piata de retail FMCG din România, Raport Octombrie 2013,Availb.at http://awsassets.panda.org/downloads/ retailer_scorecard_2013_final_1.pdf, Accessed in 2014, January 30 